\title{
Handball practice on bone health of female adolescents: evaluation of an eight-month competitive period
}

\author{
Prática de handebol e a densidade óssea de adolescentes do sexo feminino: avaliação \\ de uma etapa competitiva de oito meses
}

\section{AUTHOR'S \\ Tathyane Krahenbühl ${ }^{1}$ (D) \\ Juliano Henrique Borges ${ }^{2}$ (D) \\ Gil Guerra-Júnior ${ }^{2}$ (D) \\ Antonio de Azevedo Barros Filho ${ }^{2}$ (D) \\ Ezequiel Moreira Gonçalves ${ }^{2}$ (D) \\ 1 Universidade Federal de Goiás, Goiânia, Goiás, Brasil. \\ 2 Universidade Estadual de Campinas, Campinas, São Paulo, Brasil.}

\section{CORRESPONDING}

Tathyane Krahenbühl

tathy04n@gmail.com

Faculdade de Educação Física e Dança

- FEFD, Universidade Federal de Goiás,

Campus Samambaia. Avenida Esperança s/n

Goiânia, Goiás, Brasil. ZC: 74690-900.

DOI

$10.12820 /$ rbafs. $24 \mathrm{e} 0075$

\section{(cc) BY-NC-SA}

This work is licensed under the Creative Commons Attribution-NonCommercial-ShareAlike 4.0 International License

\begin{abstract}
A strategy to prevent bone loss diseases (i.e., osteoporosis) would be to enhance the increase of bone mass during childhood and adolescence. The purpose of this study was to compare bone mineral density (BMD) and bone mineral content (BMC) between female adolescent handball players and peers who did not play (control group), and to assess the changes in BMD and BMC after eight-months of competitive period. Fifty-eight female adolescents (12-17 years old) were allocated into two groups: handball players (HG: $n=27$ ) and control group (CG: $n=31$ ). BMC and BMD were measured using dual-energy $\mathrm{X}$-ray absorptiometry, and $\mathrm{z}$-scores were calculated. Sexual maturity, menarche, peak height velocity (PHV), sun exposure and calcium intake were assessed. At baseline, the handball players showed greater BMC and BMD than control group $(\mathrm{p}<0.05)$. These differences between groups disappeared after adjusting for weight, $\mathrm{BMI}$, menarche and lean soft tissue. After competitive period, significant time-effects for BMC and BMD of total TBLH and lumbar spine $(p<0.01)$ were observed in the handball players. HG increased BMC and BMD of total body and lumbar spine after eight-month. The $\mathrm{Z}$-score analysis showed significant group effects with greater BMD of total body, lumbar spine, femur and hip than control group. The results showed that after eight-month competitive handball period, there was an increase in BMD of total body for handball players.
\end{abstract}

Keywords: Sport; Adolescent; DXA; Bone density; Longitudinal study.

RESUMO

Uma estratégia para prevenir doenças relacionadas a baixa densidade óssea, como a osteoporose, é aumentar o incremento da massa óssea durante a infância e a adolescência. O objetivo deste estudo foi comparar a densidade mineral óssea (DMO) e o conteúdo mineral ósseo (CMO) de adolescentes jogadoras de handebol com adolescentes da mesma idade que não jogavam (grupo controle) e avaliar a resposta da DMO e CMO ao longo de oito meses de temporada competitiva de handebol. Um grupo de 58 adolescentes do sexo feminino (12 a 17 anos de idade) foram alocadas em dois grupos: jogadoras de handebol (HG: $n=27)$ e grupo controle (GC: $n=31)$. O BMC e o BMD e respectivo escore- $Z$ foram medidos pela absorciometria por raios $X$ de dupla energia. Maturidade sexual, menarca, pico de velocidade de crescimento (PHV), exposição ao sol e ingestão de cálcio foram avaliados. No início, as jogadoras de handebol apresentaram maior $C M O e$ $D M O$ do que o grupo controle $(p<0.05)$. Essas diferenças entre os grupos desapareceram após ajuste para peso, IMC, menarca e massa magra. O HG aumentou a CMO e a DMO do corpo total e da coluna lombar após oito meses. A análise do escore $Z$ mostrou maior DMO do corpo total, coluna lombar, fêmur e quadril no $H G$ do que no CG. Os resultados mostraram que, após um periodo competitivo de handebol de oito meses, houve um aumento na DMO do corpo total das jogadoras de handebol. Os resultados mostram que oito meses de temporada competitiva no handebol pode induzir um aumento no crescimento ósseo quando comparado a adolescentes do sexo feminino que tinham valores similares de BMD e BMC no início do estudo.

Palavras-chave: Esporte; Mulheres; Densidade óssea; Adolescentes; Estudo longitudinal.

\section{Introduction}

Osteoporosis is a disease that mostly affects postmenopausal women, and the incidence of osteoporotic fractures is strongly related to bone mass, which depends on the amount of bone mass acquired throughout life, especially at puberty and early adulthood ${ }^{1}$. A strategy to prevent bone diseases during life course would be to enhance the accumulation of bone mass during childhood and adolescence ${ }^{2}$.

Several factors may influence the accumulation of bone structure during the growth process ${ }^{3,4}$. Physical activity has been demonstrated to an important role on 
bone health improvements 3,5 . Therefore, regular physical activity practice is associated with increased bone mineral density (BMD), especially in women ${ }^{6}$.

A mechanism that may explain bone mass improvements induced by physical activity, probably come from mechanical tensions and compressions from skeletal muscle contractions induced from body weight overload during the movement ${ }^{7}$. And the concept of "muscle-bone unit" suggests that bone strength is dependent mainly from muscle actions that provide high mechanical load and strain on bone structure ${ }^{1}$. Thus, skeletal muscle contractions promote mechanical strain on bone structure, inducing bone remodeling and consequently determining its hypertrophy ${ }^{7}$.

The effects of the sports practice on BMD are different according to each sport ${ }^{8-10}$. Weight-bearing activities have a great importance to increase regional bone mass, mainly in those regions where activities induce great impacts ${ }^{11,12}$. Sports such as gymnastics demonstrates BMD increases, mainly in regional bone as lumbar spine and femur ${ }^{11,13}$.

Weight-bearing sports demonstrate positive effects on regional BMD, may be explained by to specific actions, such as changes of direction and large ground reaction forces that can promote great bone deposition in adolescents during maturational stage ${ }^{14}$. Handball is a sport that involves large numbers of high-speed short runs, changes of direction, jumps and landings, which cause high mechanical stress the lower limbs. Also, handball presents upper limbs actions, such as of throwing, blocking and defensive actions, resulting in osteogenic reactions in the axial and appendicular regions ${ }^{15}$. It is well established that girls at the puberty stage that practice handball present higher bone health compared with those that do not practice the sport ${ }^{10,15,16}$. However, these are cross-sectional studies, and a longitudinal analysis with handball young players is needed in order to understand the changes on the variables among subjects who are enrolled in a sport program.

Besides, handball is a popular sport in many countries, and its practice is easily accessible. Is a sport that youth participation is growing, especially at school age and knowing about its long-term benefits can help to create strategies that promote the health of children and young people. However, is important to investigate if a competitive handball period is enough to optimize the regional bone structure of adolescents.

Therefore, the aim of this study was to compare $\mathrm{BMD}$ and bone mineral content (BMC) between fe- male adolescent handball players and peers who did not play (control group), and to assess the changes in BMD and BMC after eight-months of competitive period.

\section{Methods}

This is a longitudinal study that included into two stages: 1) comparison between the bone parameters between the control group and the handball group at the beginning of the study and; 2) verification of the bone accumulation during the competitive handball period. Procedures were approved by Research Ethics Committee of the University of Campinas, Brazil, and conformed to the declaration of Helsinki for studies involving humans (CAAE 37292814.9.0000.5404). All subjects gave informed consent.

Ninety-two teenage girls were initially enrolled in this study. Subjects were assigned into two different groups: control group $(\mathrm{CG}, \mathrm{n}=42)$ or handball players group $(\mathrm{HG}, \mathrm{n}=50)$. Several handball teams and schools from metropolitan region of Campinas, São Paulo, Brazil, were contacted and invited to participate. The schools and clubs they authorized were visited by the researchers, who explained the purpose of the study, and the volunteers who authorized the participation had their day and time scheduled for the evaluations. Handball players were from three different teams at São Paulo state, Brazil, and voluntary healthy subjects (control group) had the same age and sex and were from three cities of São Paulo state, Brazil.

The inclusion criteria for entry into the study were: 1) aged between 12 and 17 years old; 2) no fractures or use of medication that affect bone metabolism in the last six months (e.g., corticoids); 3) no physical limitation that prevented the measurement procedures; 4) experienced menarche before the measurements; and 5) currently be between Tanner stages III and $V^{17}$.

Subjects enrolled in HG were adolescents participating in competitive handball practice (regional and state competitions) within a minimum of past six months before the study begin. Competitive handball season comprises the period that teams are training and participating in official handball matches. Handball players were evaluated prior to starting official matches and team training, and after eight months, when the competition was finalized and the recess/vacation started; this was the period of the final evaluation.

The minimum frequency of two training session/ week with at least one hour and 30 minutes each session, i.e., 3 hours/week were considered to be included 
in this group. Eighteen subjects gave up the handball practice during the study, three subjects did not achieve the menarche, and two subjects were $>18$ years old. Twenty-seven subjects were included in the HG.

Subjects enrolled in CG were adolescents from several public schools. Avoiding confounding factors, three subjects who was practicing physical and/or sports activities out of the school physical education classes; three subjects > 18 years old, and five subjects that did not achieve the menarche were excluded. Thirty-one subjects were included in the CG.

Measures were performed in the Center for Investigation in Pediatrics (University of Campinas, Brazil) at baseline (T0), February and March in both groups and after eight months of a competitive handball period (November and December) only for HG (T1), for logistical reasons.

The weight was measured by Filizola digital scale ( 0 to $150 \mathrm{~kg}$ ) with precision of $0.1 \mathrm{~kg}$. Whole body height and sitting height were measured by Harpender stadiometer with precision of $0.1 \mathrm{~cm}$. The body mass index (BMI) was calculated from quotient weight $(\mathrm{kg})$ / height $\left(\mathrm{m}^{2}\right)$. Z-score of height (zHeight) and BMI (zBMI) were calculated using the software "WHO AnthropoPlus", with reference of WHO reference 2007 (61 months to 19 years $)^{18}$.

Body composition and bone parameters were determined by dual $\mathrm{x}$-ray absorptiometry (DXA) device, iDXA model (GE Healthcare Lunar, Madison, WI, USA) with the enCore ${ }^{\mathrm{TM}} 2011$ software version 13.6. Percentage of body fat (\% BF) and lean soft tissue (LST) were estimated, and also, BMC and BMD measures from total body less the head (TBLH), femoral neck (FN), Ward's triangle (WT) and the lumbar spine (L1-L4), were determined. The Z-scores of $\mathrm{BMD}$ in bone sites were determined using the iDXA software, compared with reference values from healthy subjects of the same age, sex, and ethnicity. The references used are given by the iDXA software (enCore ${ }^{\mathrm{TM}}$ 2011 software version 13.6).

Sexual maturation was measured by self-assessment according to the criteria proposed by Marshall and Tanner ${ }^{17}$. The occurrence of menarche was also examined through retrospective analysis. We also measured the somatic maturity predicting years from peak height velocity (PHV) for girls, using height, sitting height (SH), leg length (LL), weight and age according to Mirwald ${ }^{19}$ :

\section{PHV $=-9.376+\left[0.0001882 *\left(\mathrm{LL}^{*} \mathrm{SH}\right)\right]+\left[0.0022^{*}\left(\right.\right.$ age $\left.\left.{ }^{*} \mathrm{LL}\right)\right]$ $+\left[0.005841^{*}(\right.$ age $\left.\mathrm{SH})\right]-\left[0.002658^{*}\left(\right.\right.$ age ${ }^{*}$ weight $\left.)\right]+$ [0.07693*(weight/height)].}

A food frequency questionnaire was administered, estimating the daily intake of calcium ( $\mathrm{mg}$ ) according to the reference of daily nutrient intake (DRI) developed by the Institute of Medicine of the National Academies using the following formula:

$$
\mathrm{D}=(\mathrm{I}-\mathrm{EAR}) / \sqrt{ }\left(\mathrm{DpEAR}{ }^{2}\right)+\left(\mathrm{Dpinter}^{2} / \mathrm{n}\right),
$$

where I represent the daily nutrient value $(\mathrm{mg})$ from questionnaire, EAR is the estimated mean age requirement, Dinter = intrapersonal for age (respective values in specific tables), $\mathrm{n}=$ number of days. Values of $\mathrm{D} \geq 0$ were considered a suitable daily nutrient intake.

Sun exposure questionnaire was applied, which participants indicated how much time they spend outdoors according to each day of the week, and the amount of skin that is exposed to the sun.

Statistical analysis was performed using SPSS software 22.0 for windows (IBM SPSS Statistics for Windows, Armonk, NY, USA). Mean \pm standard deviation (SD) was used for descriptive analysis. To test the data normality, we used the Shapiro-Wilk. Comparisons between T1 and T0 in HG was used the paired Student's $t$-test or Wilcoxon signed-rank test. Unpaired Student's $t$-test or Mann-Whitney $U$ test was used to verify differences between $\mathrm{CG}$ and $\mathrm{HG}$ at T0. The general linear model multivariate analysis with Bonferroni correction was used to compare $\mathrm{CG}$ at $\mathrm{T} 0$ and $\mathrm{HG}$ at $\mathrm{T} 0$ adjusting the differences for LST, weight, BMI and menarche. Chisquared $x^{2}$ test was used to verify the proportion of participants in each group according to stages of pubertal status (Tanner stages). The significance level was set at $\alpha \leq 0.05$.

\section{Results}

Adolescents with different pubertal stages were homogeneously distributed, demonstrating no significant difference of proportion between groups. No significant group-effects were observed between HG at T0 vs. CG for age, height, zHeight, \%BF, Ca intake, DRI, sun exposure and PHV. However, girls from CG had more months after menarche than girls from $\mathrm{HG}$ at T0. Girls from HG had higher LST, BMI, zBMI and weight than girls from CG. HG girls significantly increased height, weight, LST, age and months after menarche, as well as a increase of PHV was observed after eight months of handball period (Table 1). 
Table 1 - Characteristics of subjects in the control group, and team-handball group before and after handball competitive period (Mean \pm SD). Campinas, Brazil, 2019 ( $\mathrm{n}=58)$.

\begin{tabular}{|c|c|c|c|c|c|}
\hline \multirow{2}{*}{ Variables } & \multirow{2}{*}{$\begin{array}{c}\text { CG } \\
(\mathrm{n}=31)\end{array}$} & \multirow{2}{*}{$\begin{array}{l}\text { HG-T0 } \\
(\mathrm{n}=27)\end{array}$} & \multirow{2}{*}{$\begin{array}{l}\text { HG-T1 } \\
(\mathrm{n}=27)\end{array}$} & \multicolumn{2}{|c|}{$\mathrm{P}$-value } \\
\hline & & & & HG-T0 vs. CG & HG-T0 vs. HG-T1 \\
\hline Age (years) & $14.70 \pm 1.42$ & $14.23 \pm 1.11$ & $14.90 \pm 1.11$ & 0.171 & 0.000 \\
\hline Height $(\mathrm{cm})$ & $160.62 \pm 6.51$ & $161.47 \pm 5.16$ & $162.23 \pm 5.05$ & 0.590 & 0.002 \\
\hline zHeight (Z-score) & $0.06 \pm 1.08$ & $0.29 \pm 0.85$ & $0.24 \pm 0.71$ & 0.392 & 0.590 \\
\hline Weight $(\mathrm{kg})$ & $55.54 \pm 11.89$ & $59.79 \pm 7.08$ & $61.10 \pm 7.19$ & $0.040 \dagger$ & 0.010 \\
\hline BMI $\left(\mathrm{kg} / \mathrm{m}^{2}\right)$ & $24.65 \pm 3.96$ & $22.88 \pm 2.09$ & $23.20 \pm 2.37$ & $0.019 \dagger$ & 0.139 \\
\hline zBMI (Z-score) & $0.39 \pm 1.14$ & $0.94 \pm 0.62$ & $0.90 \pm 0.64$ & $0.030^{*}$ & 0.566 \\
\hline$\% \mathrm{BF}$ & $32.98 \pm 6.85$ & $32.26 \pm 4.25$ & $31.90 \pm 4.81$ & 0.634 & 0.293 \\
\hline $\operatorname{LST}(\mathrm{kg})$ & $33.94 \pm 4.40$ & $38.03 \pm 4.28$ & $39.04 \pm 4.39$ & $0.005 \dagger$ & 0.000 \\
\hline $\mathrm{Ca}(\mathrm{mg} /$ day $)$ & $421.93 \pm 378.24$ & $595.40 \pm 741.46$ & $584.55 \pm 430.86$ & 0.355 & 0.930 \\
\hline DRI (score) & $0.00 \pm 0.82$ & $1.69 \pm 1.93$ & $1.66 \pm 1.04$ & 0.355 & 0.076 \\
\hline Sun exposure (score) & $27.83 \pm 6.10$ & $28.63 \pm 3.06$ & $27.81 \pm 4.16$ & 0.545 & 0.389 \\
\hline PHV (years) & $-0.41 \pm 0.75$ & $-0.87 \pm 0.80$ & $-0.40 \pm 0.74$ & 0.127 & 0.000 \\
\hline Menarche (months) & $36.22 \pm 22.46$ & $25.52 \pm 15.37$ & $33.07 \pm 15.23$ & $0.042^{*}$ & 0.000 \\
\hline \multicolumn{6}{|l|}{ Tanner Stage (\%) } \\
\hline III & 25.8 & 44.4 & 18.5 & \multicolumn{2}{|c|}{$0.076 \ddagger$} \\
\hline IV & 51.6 & 37.0 & 48.1 & \multicolumn{2}{|c|}{$0.122 \ddagger$} \\
\hline $\mathrm{V}$ & 22.6 & 18.5 & 33.3 & \multicolumn{2}{|c|}{$0.273 \ddagger$} \\
\hline
\end{tabular}

$\% \mathrm{BF}$ = percentage of body fat; $\mathrm{BMI}=$ body mass index; $\mathrm{Ca}=$ calcium intake; $\mathrm{CG}=$ control group; $\mathrm{DRI}=$ dietary reference intakes; $\mathrm{HG}-\mathrm{T} 0=$ handball group at baseline; HG-T1 = handball group after a competitive period; LST = lean soft tissue; $\mathrm{PHV}=$ peak height velocity; $\mathrm{zBMI}=$ body mass index z-score; zHeight $=$ height z-score; Significant differences $(\mathrm{p}<0.05) ; \uparrow$ Mann-Whitney test; *Test $\mathrm{T}$ Student. $\neq C h i-$ squared $\mathrm{x}^{2}$ test.

Analyzing the bone health, HG showed significantly higher values than $\mathrm{CG}$ for BMC and BMD in all analyzed bone sites at T0. The group difference disappeared when adjusted bone analysis for LST, weight, menarche and BMI. Time-effects for HG showed significant increases only for BMC of TBLH and L1-L4, also BMD of TBLH and L1-L4 after the handball period compared to T0 (Table 2).

$\mathrm{Z}$-score analysis demonstrated significant group-effects with greater BMD of TBLH ( $p=0.001), \mathrm{L} 1-\mathrm{L} 4$ $(p<0.001), F N(p<0.001)$ and WT $(p=0.005)$ for $\mathrm{HG}$ at $\mathrm{T} 0$ compared to CG. Significant time-effect for HG was observed only for TBLH ( $p<0.001)$ after the handball period compared to T0 (Figure 1).

\section{Discussion}

To our knowledge, there are no studies measuring $\mathrm{BMC}, \mathrm{BMD}$ and $\mathrm{Z}$-score values of bone sites in girls handball players during a competitive period. In this study, the handball players showed an increase in the $\mathrm{Z}$-scores of TBLH and lumbar spine, but there was no increase in the hip and femur after eight months of a competitive period.
Factors such as age, sex, physical activity, BMI, weight, and maturity may influence the bone health ${ }^{4,20}$.

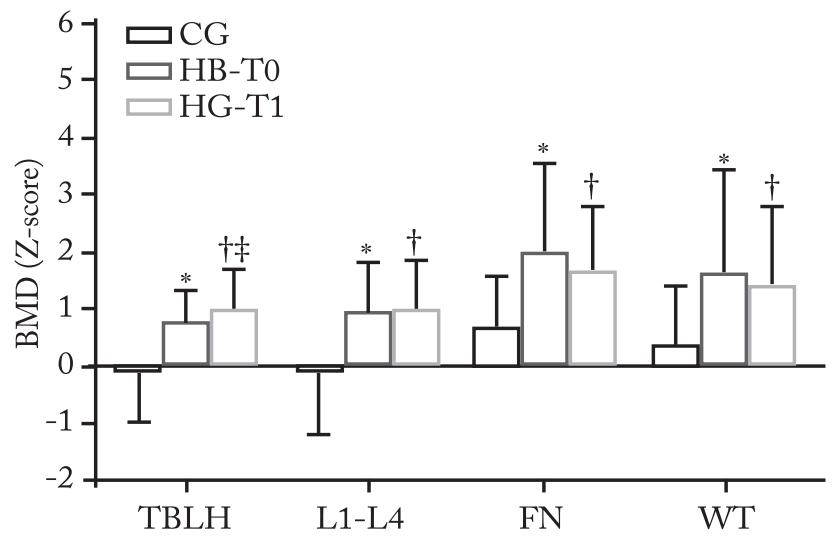

Figure 1 - Comparisons of bone mineral density (BMD) z-scores from total body less the head (TBLH), lumbar spine (L1-L4), femoral neck (FN) and Ward's triangle (WT) between girls from handball group at baseline (HG-T0) vs. girls from control group (CG); handball group after a competitive period (HG-T1) vs. CG; and HG-T0 vs. HG-T1. Campinas, Brazil, 2019 ( $\mathrm{n}=58)$.

* Significant difference between HG-T0 vs. CG ( $p<0.001)$. † Significant difference between HG-T1 vs. CG ( $p<0.001)$. \# Significant difference between HG-T0 vs. HG-T1 ( $\mathrm{p}<0.001$ ). Unpaired Student's $t$-test was used to verify differences between CG and HG at T0, and the paired Student's $t$-test was used to verify differences between $\mathrm{T} 0$ and $\mathrm{T} 1 \mathrm{for} \mathrm{HG}$. 
Table 2 - Comparison of bone health between control group, and handball group before and after handball period (Mean \pm SD). Campinas, Brazil, 2019 ( $\mathrm{n}=58)$.

\begin{tabular}{|c|c|c|c|c|c|}
\hline \multirow{2}{*}{ Variables } & \multirow{2}{*}{$\mathrm{CG}(\mathrm{n}=31)$} & \multirow{2}{*}{ HG-T0 (n = 27) } & \multirow{2}{*}{ HG-T1 $(\mathrm{n}=27)$} & \multicolumn{2}{|c|}{$\mathrm{P}$-value } \\
\hline & & & & HG-T0 vs. CG & HG-T0 vs. HG-T1 \\
\hline \multicolumn{6}{|l|}{$\mathrm{BMC}(\mathrm{g})$} \\
\hline TBLH & $1613.74 \pm 277.90$ & $1814.10 \pm 230.92$ & $1897.39 \pm 222.43$ & 0.005 & 0.000 \\
\hline $\mathrm{TBLH}_{\text {Adjusted }}$ & 1677.10 & 1741.36 & 1824.31 & 0.090 & - \\
\hline L1-L4 & $51.93 \pm 10.16$ & $58.14 \pm 9.72$ & $60.64 \pm 9.51$ & 0.022 & 0.000 \\
\hline $\mathrm{L} 1-\mathrm{L} 4_{\text {Adjusted }}$ & 53.69 & 56.11 & 58.52 & 0.285 & - \\
\hline $\mathrm{FN}$ & $4.49 \pm 0.76$ & $5.27 \pm 0.87$ & $5.31 \pm 0.63$ & 0.001 & 0.665 \\
\hline $\mathrm{FN}_{\text {Adjusted }}$ & 4.71 & 5.02 & 5.10 & 0.158 & - \\
\hline WT & $1.95 \pm 0.53$ & $2.43 \pm 0.54$ & $2.46 \pm 0.40$ & 0.001 & 0.616 \\
\hline $\mathrm{WT}_{\text {Adjusted }}$ & 2.10 & 2.26 & 2.31 & 0.251 & - \\
\hline \multicolumn{6}{|l|}{$\operatorname{BMD}\left(\mathrm{g} / \mathrm{cm}^{2}\right)$} \\
\hline TBLH & $0.92 \pm 0.09$ & $1.01 \pm 0.08$ & $1.04 \pm 0.08$ & 0.001 & 0.000 \\
\hline $\mathrm{TBLH}_{\text {Adjusted }}$ & 0.95 & 0.98 & 1.01 & 0.130 & - \\
\hline L1-L4 & $1.07 \pm 0.12$ & $1.17 \pm 0.21$ & $1.22 \pm 0.21$ & 0.005 & 0.004 \\
\hline $\mathrm{L} 1-\mathrm{L} 4_{\text {Adjusted }}$ & 1.09 & 1.14 & 1.19 & 0.162 & - \\
\hline $\mathrm{FN}$ & $1.06 \pm 0.13$ & $1.23 \pm 0.15$ & $1.21 \pm 0.15$ & 0.001 & 0.273 \\
\hline $\mathrm{FN}_{\text {Adjusted }}$ & 1.10 & 1.19 & 1.17 & 0.096 & - \\
\hline WT & $0.98 \pm 0.16$ & $1.15 \pm 0.12$ & $1.22 \pm 0.12$ & 0.002 & 0.464 \\
\hline $\mathrm{WT}_{\text {Adjusted }}$ & 1.02 & 1.10 & 1.09 & 0.242 & \\
\hline
\end{tabular}

$\mathrm{BMC}=$ bone mineral content; $\mathrm{BMD}=$ bone mineral density; $\mathrm{CG}=$ control group; FN = femoral neck; HG-T0 = handball group at baseline; HG-T1 = handball group after a competitive period; L1-L4 = lumbar spine; TBLH = total body less head; WT = Ward's triangle. Adjustments analyses were performed using weight, body mass index, lean soft tissue and menarche as covariates. Significant differences ( $p<0.05)$, Unpaired Student's t-test CG and HG at T0.

To avoid bias during the analysis, only female subjects with similar age were selected in this study. However, we observed significant different between handball players and control group for weight, BMI, lean soft tissue and menarche. Thus, bone analysis was also adjusted for these variables.

In order to attenuate the effects of growth, all analysis were performed using both the absolute data and $\mathrm{Z}$-score, and the groups were homogeneous in the Tanner's stage and PHV. Absolute values of BMD and BMC have been shown in studies, however, this study demonstrated comparisons of $Z$-score between groups. Z-scores are calculated by DXA software using the BMD and compared with reference values from healthy subjects of the same age, sex, and ethnicity ${ }^{21}$, which allows adjusting data according to these variables. Handball players demonstrated significantly higher $\mathrm{Z}$-scores of BMD than control group in our study, even when the values were adjusted for the LST, demonstrated high bone status expected for the same age and sex in specific bone sites as well as systemic bone.
When analyzing the absolute values of BMC and $\mathrm{BMD}$, handball players showed higher values in all measured bone sites when compared with the control group at T0 (without adjustments). These data are in agreement with other cross-sectional studies, in which higher bone quality ${ }^{22}$ and bone density ${ }^{23}$ values were observed when compared to adolescents of the same age (control group). Studies also demonstrated that handball players have higher $\mathrm{BMD}$ and $\mathrm{BMC}$ when compared to sedentary individuals with the same age and sex ${ }^{10,15,16,24}$.

Furthermore, the subjects showed no differences between groups for $\% \mathrm{BF}$, but they showed an average difference of $\sim 5 \mathrm{~kg}$ of LST. Thus, greater muscle development in these subjects may support better bone development. It is well established that muscle mass has a great influence on bone mass ${ }^{1}$. The high number of muscle contractions induces bone changes. If they have larger muscles, then force should hypothetically higher as well. This further supports the bone muscle unit and mechanistic hypothesis ${ }^{1}$. Accordingly, when we adjusted bone analysis for LST, the differences between the handball group and control group disappeared at baseline. 
These findings are in agreement with some cross-sectional studies, which found association between handball practice with increased physical fitness, lean mass and bone mass ${ }^{10,15,16,22,23}$. Subjects in the handball group had practice in this sport at least six months before the study begin, which may explain these differences between groups at baseline.

This adjusted for LST result is in agreement with the background that sport participation also improves muscle mass (weight and BMI); thus, high lean mass is also linked with bone status improvements ${ }^{21}$. So, handball participation is associated with both high bone status and high lean mass ${ }^{4,5}$. The main mechanical stimulus to bone comes from skeletal muscle contractions, which promote mechanical strain on bone structure to determine its hypertrophy as a consequence of bone remodelling. Therefore, sports that induce higher muscle tension promote greater bone resistance and consequently greater remodeling ${ }^{7,8}$.

When we compare the athletes at baseline and after the competitive period, this study found a relevant result by showing that a competitive period can optimize BMD and BMC in bone sites such as TBLH.

Different than expected, we did not observe significant change on femoral and hip BMC and BMD after the handball period. Added to this result, the $\mathrm{Z}$-score did not increase for femur and hip, but according to the ISCD Pediatric Official Positions ${ }^{25}$, because of the unstable variability in skeletal development in the hip, it is not a preferred site for evaluation in growing children. And, other possible explanation is the subjects already had high adaptation level of bone, as demonstrated in handball players at baseline, when we analyzed BMD Z-scores (Figure 1).

Although we did not find time-effects of handball period for $Z$-scores of femoral and lumbar BMD, BMD $Z$-score from TBLH showed significant time-effects. Therefore, improvements of regional bone health may be related to the characteristics of each sport and body composition changes ${ }^{26}$. Some studies demonstrate the importance to stimulation of muscle contraction to bone formation ${ }^{1}$, may explaining our findings, that greater regional bone health from handball players are linked with the sport characteristics. Sports with high muscle tension and high impact provide greater degrees of bone remodelling ${ }^{8}$, explaining the findings of the present study that higher bone status may be strongly linked with the physical and technical demands of handball. This corroborates with our hypothesis that physical actions re- quired in handball such as defensive blocks, changes in direction, sprints, jumps, contact, throwing, falls, providing mechanical overload on the bone ${ }^{7}$.

Weight-bearing sports demonstrate an essential characteristic to improve bone health, that was observed in subjects who practice gymnastics ${ }^{13}$, volleyball ${ }^{6,28}$ and soccer $^{27,29}$. Therefore, high-impact activities, jumps and falls which are characteristics from these sports ${ }^{8}$, may promote bone deposition, and optimizing the peak bone density, caused by different types of stress loads in the bone, such as torsion, flexion, compression.

A greater $\mathrm{BMD}$ in adolescents is related to the prevention of diseases, such as osteoporosis and lower occurrence of fractures in old age $\mathrm{e}^{30}$, thus, the competitive practice of handball is a great strategy to induce osteogenic effects optimizing the bone health during the adolescence, and consequently may reducing osteoporosis risk and fractures during senescence, as it is possible to observe with $Z$ score data.

Some limitations of this study need to be underlined. First, the training load determining the intensity of training was not controlled, on the other hand, volume of training such as, total time, frequency and duration of training were measured.

Second, subjects in the control group were measured only at baseline. Besides this study did not present an experimental design (randomized controlled trial), this makes impossible to identify the effect of the competitive handball practice and the improvement of bone health in these adolescents. However, we believe the findings of this study bring new perspectives to sports and health sciences regarding improvements of bone health in this population.

Some strengths of this study can be highlighted, such that the longitudinal analysis of handball players was strength to show that bone accrual is still occurring despite having somewhat higher BMD/BMC than controls, thus, verifying time-effects on $\mathrm{BMD}$ increases during a competitive period. In addition, the use of DXA allows regional bone measures, also using $\mathrm{Z}$-score analysis controlling confounding factors, thus, improving the reliability of this study's findings.

We conclude that handball players had a great bone status, especially in Z-score values, and the participation in competitive practice of handball shown to be linked with higher muscle mass and bone status. The competitive practice of handball can be a great strategy to optimize the bone health during the growth in the adolescence. 


\section{Conflict of interest}

The authors declare no conflict of interest.

\section{Authors' Contributions}

Krahenbühl T, participated in all stages from drafting, literature search, data analysis, to final review. Borges $\mathrm{JH}$, participated in the study design and data analysis. Guerra-Junior G, participated in the critical and final review of the study. Barros-Filho AA, participated in the study design and critical analysis. Gonçalves EM, participated in the study design, data analysis, critical review and final study.

\section{Acknowledgements}

The authors thank the Faculty of Medical Sciences and the Growth and Development Laboratory of the State University of Campinas for their academic support. We also thank the National Research Council (CNPq), Universal Notice MCTI / CNPq no. 14/2014, Process: 462310 / 2014-0 for the financial support to one of the authors.

\section{References}

1. Frost HM, Schonau E. The "muscle-bone unit" in children and adolescents: a 2000 overview. J Pediatr Endocrinol Metab. 2000;13(6):571-90.

2. Matkovic V, Jelic T, Wardlaw GM, Ilich JZ, Goel PK, Wright JK, et al. Timing of peak bone mass in caucasian females and its implication for the prevention of osteoporosis. Inference from a cross-sectional model. J Clin Invest. 1994;93(2):799808.

3. Bailey CA, Brooke-Wavell K. Exercise for optimising peak bone mass in women. Proc Nutr Soc. 2008;67(1):9-18.

4. Krahenbühl T, Goncalves EM, Costa ET, Barros-Filho AA. Factors that influence bone mass of healthy children and adolescents measured by quantitative ultrasound at the hand phalanges: a systematic review. Rev Paul Pediatr. 2014;32(3):266-72.

5. Andreoli A, Monteleone M, Van Loan M, Promenzio L, Tarantino U, De Lorenzo A. Effects of different sports on bone density and muscle mass in highly trained athletes. Med Sci Sports Exerc. 2001;33(4):507-11.

6. Alfredson H, Nordström P, Pietilä T, Lorentzon R. Longterm loading and regional bone mass of the arm in female volleyball players. Calcif Tissue Int. 1998;62(4):303-8.

7. Cornwall MW. Biomechanics of noncontractile tissue. A review. Phys Ther. 1984;64(12):869-1873.

8. Tenforde AS, Fredericson M. Influence of sports participation on bone health in the young athlete: a review of the literature. PM\&R. 2011;3(9):861-7.

9. Silva CC, Goldberg TB, Teixeira AS, Dalmas JC. The impact of different types of physical activity on total and regional bone mineral density in young Brazilian athletes. J Sports Sci. 2011;29(3):227-34.

10. Ubago-Guisado E, Gomez-Cabello A, Sanchez-Sanchez J, García-Unanue J, Gallardo L. Influence of different sports on bone mass in growing girls. J Sports Sci. 2015;33(16):1710-8.

11. Maimoun L, Sultan C. Effects of physical activity on bone remodeling. Metab Clin Exp. 2011;60(3):373-88.
12. Maimoun L, Coste $O$, Philibert $P$, Briot K, Mura T, Galtier $\mathrm{F}$, et al. Peripubertal female athletes in high-impact sports show improved bone mass acquisition and bone geometry. Metabolism. 2013;62(8):1088-98.

13. Burt LA, Ducher G, Naughton GA, Courteix D, Greene DA. Gymnastics participation is associated with skeletal benefits in the distal forearm: a 6-month study using peripheral quantitative computed tomography. J Musculoskelet Neuronal Interact. 2013;13(4):395-404.

14. Heinonen A, Sievänen H, Kannus P, Oja P, Pasanen M, Vuori I. High-impact exercise and bones of growing girls: a 9-month controlled trial. Osteoporos Int. 2000;11(12):1010-7.

15. Vicente-Rodriguez G, Dorado C, Perez-Gomez J, Gonzalez-Henriquez JJ, Calbet JAL. Enhanced bone mass and physical fitness in young female handball players. Bone. 2014;35(5):1208-15.

16. Mrabet Bahri D, Selmi A, Abdelkefi M, Mbarek M, Sahli H, Sellami S. Study of bone mineral density in adolescent handball players: a study of 20 cases. Tunis Med. 2013;91(11):633-7.

17. Marshall WA, Tanner JM. Variations in pattern of pubertal changes in girls. Arch Dis Child. 1969;44(235):291-303.

18. Onis M, Onyango AW, Borghi E, Siyam A, Nishida C, Siekmann J. Developmentof a WHO growth reference for school-aged children and adolescents. Bull World Health Organ. 2007;85(9):660-7.

19. Mirwald RL, Baxter-Jones AD, Bailey DA, Beunen GP. An assessment of maturity from anthropometric measurements. Med Sci Sports Exerc.2002;34(4):689-94.

20. Theintz G, Buchs B, Rizzoli R, Slosman D, Clavien H, Sizonenko PC, Bonjour JP. Longitudinal monitoring of bone mass accumulation in healthy adolescents: evidence for a marked reduction after 16 years of age at the levels of lumbar spine and femoral neck in female subjects. J Clin Endocrinol Metab. 1992;75(4):1060-5.

21. Bacharach LK, Gordon CM. Bone densitometry in children and adolescents. Pediatrics. 2016;138(4):e20162398.

22. Krahenbuhl T, Gonçalves EM, Guimarães RDF, GuerraJúnior G, Barros-Filho ADA. Competitive swimming and handball participation have a positive influence on bone parameters as assessed by phalangeal quantitative ultrasound in female adolescents. Pediatr Exerc Sci. 2016;28(3):423-30.

23. KrahenbühlT, Borges JH, Barros Filho ADA, Guerra-Junior $\mathrm{G}$, Gonçalves EM. Assessment of bone mineral density in young female handball players. Rev Bras Cineantropom Desempenho Hum. 2018; 20(1):102-13.

24. Boshnjaku A, Dimauro I, Krasniqi E, Grazioli E, Tschan H, Migliaccio S, et al. Effect of sport training on forearm bone sites in female handball and soccer players. J Sports Med Phys Fitness. 2016;56(12):1503-10

25. Crabtree NJ, Arabi A, Bachrach LK, Fewtrell M, Fuleihan $\mathrm{GEH}$, Kecskemethy $\mathrm{HH}$, et al. Dual-energy X-ray absorptiometry interpretation and reporting in children and adolescents: the revised 2013 ISCD Pediatric Official Positions. J Clin Densitom. 2014;17(2):225-42.

26. Behringer M, Gruetzner S, McCourt M, Mester J. Effects of weight-bearing activities on bone mineral content and density in children and adolescents: A meta-analysis. J Bone Miner Res. 2014;29(2):467-78.

27. Ferry B, Duclos M, Burt L, Therre P, Le Gall F, Jaffré C, et al. Bone geometry and strength adaptations to physical constraints inherent in different sports: comparison between elite female soccer players and swimmers. J Bone Miner Metab. 2011;29(3):342-51. 
28. Mesquita WG, Fonseca RMC, França NM. Influência do voleibol na densidade mineral óssea de adolescentes do sexo feminino. Rev Bras Med Esp. 2008;14:500-3.

29. Ferry B, Lespessailles E, Rochcongar P, Duclos M, Courteix D. Bone health during late adolescence: effects of an 8-month training program on bone geometry in female athletes. Joint Bone Spine. 2013;80(1):57-63.
30. Lynch KR, Kemper HC, Turi-Lynch B, Agostinete RR, Ito IH, Luiz-De-Marco R, Rodrigues-Junior MA, Fernandes RA. 2016 Impact sports and bone fractures among adolescents. J Sports Sci. 2017;35(24), 2421-6.

Received: $16 / 04 / 2019$

Approved: 25/08/2019

\section{Quote this article as:}

Krahenbühl T, Borges JH, Guerra-Junior G, Barros Filho AA, Gonçalves EM. Handball practice on bone health of female adolescents: evaluation of an eight-month competitive period. Rev Bras Ati Fis Saúde. 2019;24:e0075. DOI: 10.12820/rbafs.24e0075 